\title{
Advance Oxidation Protein Products (AOPPs) of Newborn at Risk of Sepsis as Novel Parameter for Early-Onset Neonatal Sepsis
}

\author{
Ari Yunanto, Rizky Taufan Firdaus, Triawanti, and Eko Suhartono
}

\begin{abstract}
Neonatal sepsis is a clinical syndrome of bacteremia and divided into two different types, early-onset neonatal sepsis and late-onset neonatal sepsis. Sepsis promotes the unbalanced production of oxidant and anti-oxidant substances, causing an excess of free oxygen compounds. Early markers of neonatal sepsis have been studied in recent years, and this study proposed another parameter to detect early-onset neonatal sepsis with the use of advance oxidation protein products (AOPPs). This study was conducted in April - June 2012, saliva and serum specimens were taken from 81 newborns, in which 39 infants were at risk of sepsis and 42 infants were healthy and served as a control group. Data was analyzed by using Mann-Whitney test and Spearman correlation test. This study suggested that there is significant difference between AOPPs level on the case group compare to the control group. This study also found that there is significant difference between salivary AOPPs level compare to serum AOPPs level. As the conclusion, this study proposed that the AOPPs parameter may be used as another marker to detect early-onset neonatal sepsis.
\end{abstract}

Index Terms-Early-onset neonatal sepsis, free oxygen compounds, AOPPs.

\section{INTRODUCTION}

Neonatal sepsis remains a leading cause of neonatal morbidity and mortality despite recent advances in neonatal intensive care. Neonatal sepsis is a clinical syndrome of bacteremia characterized by systemic signs and symptoms of infection in the first month of life. Sepsis divided into two different types, early-onset neonatal sepsis and late-onset neonatal sepsis. Early-onset neonatal sepsis (EONS) which manifests in the first 72 hours of life (up to 7 days) and late-onset neonatal sepsis (LONS) which incidence peaks in the 2 nd to 3 rd week of postnatal life. Differentiating early and late neonatal sepsis is clinically important because in early neonatal sepsis, the infectious organisms are acquired during the delivery, whereas in late sepsis the infecting organisms are mostly acquired after birth, from either hospital or community sources. Activation of natural immune system describes defense mechanism against infectious agents.

Manuscript received October 14, 2013; revised December 25, 2013.

Ari Yunanto is with the Pediatric Department Ulin General Hospital/ Faculty of Medicine Lambung Mangkurat University, Banjarmasin, Indonesia (e-mail: ariefkaunlam@gmail.com).

Rizky Taufan Firdaus is with the Reserch Unit on Maternal and Perinatal Mutiara Bunda Mother and Child Hospital, Martapura, Indonesia (e-mail: weiki_5150@yahoo.com).

Triawanti and Eko Suhartono are with the Medical Chemistry, Biochemistry Department Faculty of Medicine Lambung Mangkurat University, Banjarmasin, Indonesia (e-mail: tria_fkunlam@yahoo.co.id; ekoantioksidan@yahoo.com).
Immune cells that ruled in respond to this activity such as monocyte, macrofage, dendritic cell, and neutrophil [1]-[3].

Neutrophils use bactericidal pathways that oxygen-dependent or oxygen-independent as a weapon to eliminate infectious agents. In response to bacterial pathogens entrance, neutrophils inserted into the infected tissue, then activate to form a reactive oxygen compounds, this event called respiratory burst. As a consequence of respiratory burst, a number of oxygen-containing compounds are produced. In this process NADPH oxidase catalyzes the formation of superoxide anions part of which are converted to hydrogen peroxide and singlet oxygen. Moreover, superoxide anion can react with hydrogen peroxide resulting in the formation of hydroxyl radicals and more singlet oxygen. Altogether, these reactions result in the production of toxic oxygen compounds such as superoxide anion, hydrogen peroxide, singlet oxygen, and hydroxyl radicals. Myeloperoxidase is released into the phagosome as azurophilic granules fuse with the phagosome. This enzyme utilizes hydrogen peroxide and chloride ions to form hypochlorite, which represents a highly toxic substance that kills pathogens [4].

Reactive oxygen species such as hydrogen peroxide, superoxide anion, hydroxyl radical, etc can trigger oxidative damage to macromolecules, leading to lipid peroxidation, amino acid chains oxidation, cross links protein formation, polypeptide chain oxidation forming protein fragmentation, DNA strands ruptured. Furthermore, through the degranulation process, occurred secretion of several chemical compounds, especially superoxide dismutase (SOD) and peroxidase enzyme [4].

Those enzymes are involved due to oxygen consumption by neutrophil which produce anion superoxide than dismutated into hydrogen peroxide. Hydrogen peroxides are able to kill bacterias on sepsis when they are in high concentration while superoxides anions are not able to kill bacterias directly. Hydroxyl radicals are oxygen radicals that most reactive and very cytotoxic. Hydrogen peroxide $\left(\mathrm{H}_{2} \mathrm{O}_{2}\right)$ and superoxide anion $\left(\mathrm{O}_{2}^{-}\right)$are less reactive and have longer half time than hydroxyl radicals [3].

Protein carbonyl derivates (aldehydes and ketones) are produced on protein side chains when they are oxidized by the reactive oxygen species. Protein carbonyl content is actually the most general indicator and by far the most commonly used marker of protein oxidation, and accumulation of protein carbonyls has been observed in several human diseases including Alzheimer's disease (AD), diabetes, inflammatory bowel disease (IBD), and arthritis [5]. Several methods to diagnose early-onset neonatal sepsis have been reported, such as procalcitonin and c-reactive protein 
[6]-[8]. Recently, another type of oxidized protein beside protein carbonyl has been investigated called advance oxidation protein product (AOPPs). AOPPs is dityrosine containing cross linked protein products, a definition that is important as it excludes protein aggregates that are formed by disulphide bonds as a result of oxidative stress. Therefore, AOPPs is a good oxidative stress marker, which originates under oxidative and carbonyl stress and increase global inflammatory activity. Several studies have use AOPPs as a marker for several disease. AOPPs has been used as oxidative stress marker for nasal polyposis and acute coronary syndrome and also as inflammatory marker for liver cirrhosis and chronic renal failure [6]-[9]. The well-established relationship between AOPP response and induced damage makes this simple, fast and inexpensive automated technique applicable in daily routine laboratory practice for assessing and monitoring oxidative stress in critically ill or other patients [10].

The use of AOPPs as marker for early-onset of neonatal sepsis (EONS) were never been investigated, therefore a study to use this method as a marker for EONS should be performed. We used other parameter to detect EONS through salivary and serum AOPPs, therefore AOPPs can be used as new parameter for EONS.

\section{MATERIAL AND METHODS}

The cross-sectional prospective study was conducted from April to June 2012 in the Division of Neonatology, Department of Child Health, Lambung Mangkurat University Faculty of Medicine/Ulin General Hospital, Banjarmasin. Laboratory tests were conducted at Medical Chemistry/ Biochemistry Department Faculty of Medicine Lambung Mangkurat University, Banjarmasin. Saliva and serum specimens were taken from 81 newborns, of which 39 infants were at risk of sepsis and 42 infants were healthy and served as a control group. All subject's parents provided with a written informed consent. Saliva specimens ( $3 \mathrm{ml}$ each) were taken via suction from the oropharynx according to standard procedures for neonatal resuscitation. While serum specimens were taken from peripheral veins blood.

Subjects in the sepsis risk group were included on the basis of having at least 1 major criteria or 2 minor criteria. Major risk criteria were membranes ruptured for $>24$ hours, maternal fever with intrapartum temperature $>38{ }^{\circ} \mathrm{C}$, chorioamnionitis, fetal heart rate persisting at $>160$ times/minute or foul-smelling amniotic fluid. Minor risk criteria were membranes ruptured for $>12$ hours, maternal fever with intrapartum temperature $>37.5{ }^{0} \mathrm{C}$, low Apgar score ( $<5$ at the 1 st minute, $<7$ at the 5 th minute), very low birth weight baby (VLBWB) of $<1500$ grams, gestational age < 37 weeks, multiple pregnancy, foul-smelling vaginal discharge, maternal urinary tract infection (UTI) or suspected untreated maternal UTI [9].

\section{A. AOPPs Determination}

Salivary and serum AOPPs measurement were made by spectrophotometric methods as describe by Witko-Sarsat et al [11].

\section{B. Protein Carbonyl Assay}

Sample derivatization: Two 1-mg aliquots are needed for each sample to be assayed. Samples are extracted in a final concentration of $10 \%(\mathrm{w} / \mathrm{v})$ TCA. The precipitates are treated with $500 \mu \mathrm{L}$ of $0.2 \% \mathrm{DNPH}$ or $500 \mu \mathrm{L}$ of $2 \mathrm{M} \mathrm{HCl}$. Samples are incubated at room temperature for $1 \mathrm{~h}$ with vortexing at 5 -min intervals. The proteins are then precipitated by adding $55 \mu \mathrm{L}$ of $100 \%$ TCA. The pellets are centrifuged and washed three times with $500 \mu \mathrm{L}$ of the ethanol:ethyl acetate mixture. The pellet is then dissolved in $600 \mu \mathrm{L}$ of $6 \mathrm{M}$ guanidine hydrochloride. The carbonyl content is determined by reading the absorbance at the optimum wavelength $390 \mathrm{~nm}$ [5], [12]-[14].

\section{Hydrogen Peroxide Assay}

$90 \mathrm{ml}$ of sample, $10 \mathrm{ml}$ of methanol and $900 \mathrm{ml}$ of xylenol orange reagent containing ferrous ions were added successively and absorbance was noted at $560 \mathrm{~nm}$ [15].

Data are presented as means \pm SD. The determinations were performed on saliva and serum from 39 newborns with sepsis risk (Case group) and 42 healthy newborns (Control group). The differences were examined by the Mann-Withney test and the corellation were examined by Spearman Correlation using SPSS for Windows version 17. For all outcomes, a nominal $p$-value of $p<0.05$ was considered significant.

\section{RESULTS}

From Table I. Mean of AOPPs, carbonyls, and hydrogen peroxides level both, from saliva and serum samples shows that the case group is higher than the control group and it is significant $(p<0.005)$.

TABLE I: MANN-WHITNEY COMPARISON OF PARAMETERS RESULTS BY RISK FACTOR (MEAN \pm SD)

\begin{tabular}{cccc}
\hline \hline Parameter & $\begin{array}{c}\text { Case group } \\
(n=39)\end{array}$ & $\begin{array}{c}\text { Control group } \\
(n=42)\end{array}$ & $p$-value \\
\hline Salivary & & & \\
\hline $\mathrm{AOPP}(\mu \mathrm{M} / \mathrm{L})$ & $7.363 \pm 4.849$ & $3.893 \pm 1.924$ & $0.000^{*}$ \\
\hline Carbonyl $(\mu \mathrm{M})$ & $6.040 \pm 4.451$ & $1.699 \pm 1.565$ & $0.000^{*}$ \\
\hline $\mathrm{H}_{2} \mathrm{O}_{2}(\mu \mathrm{M})$ & $79.659 \pm 0.237$ & $37.465 \pm 0.314$ & $0.000^{*}$ \\
\hline $\mathrm{Serum}$ & & & \\
\hline $\mathrm{AOPP}(\mu \mathrm{M} / \mathrm{L})$ & $11.569 \pm 9.142$ & $6.271 \pm 2.267$ & $0.000^{*}$ \\
\hline $\mathrm{Carbonyl}(\mu \mathrm{M})$ & $8.450 \pm 6.871$ & $2.102 \pm 1.364$ & $0.000^{*}$ \\
\hline $\mathrm{H}_{2} \mathrm{O}_{2}(\mu \mathrm{M})$ & $79.106 \pm 0.825$ & $36.736 \pm 0.747$ & $0.000^{*}$ \\
\hline \hline$)=$ a significant difference/ significantly $(p<0.05)$ &
\end{tabular}

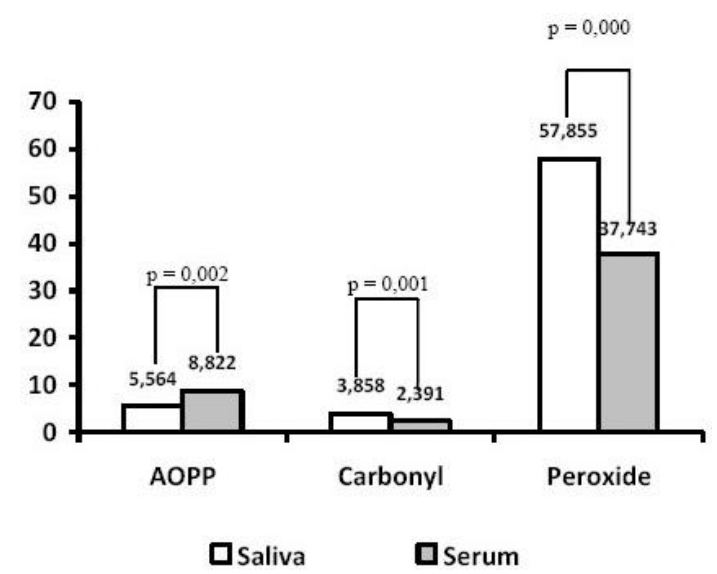

Fig. 1. Salivary and serum parameters comparison by Mann-Whitney test.

From Fig. 1, Mean of salivary and serum AOPPs, carbonyls, and hydrogen peroxides comparison shows there is significant difference between both samples $(p<0.05)$. 


\section{Discussion}

Neonatal sepsis causes significant mortality and morbidity in infants, especially preterm infants. Despite considerable advances of neonatal intensive care medicine, the pathogenesis of neonatal sepsis with its rapid progression from infection to a systemic inflammatory response still remains little understood. Beyond doubt, sepsis is a clinical manifestation of a dysregulated immune response to invasive pathogens. However, numerous clinical trials with immunomodulatory approaches for neonates with suspected or proven infections failed to improve survival [16].

In physiological conditions, there is a balance condition between the formation of reactive oxidizing/oxygen species and their elimination by endogenous antioxidant scavenging compounds. Oxidative stress occurs when this balance is disrupted by inadequate antioxidative defences, including superoxide dismutase (SOD), catalase, and peroxidase and/or by excessive production of reactive oxygen species, including superoxide, hydrogen peroxide and hydroxyl radicals [9].

In vivo measurement of oxidative stress is complicated, and practical and easy methods of measurement are still being investigated. Several methods has been performed to measure oxidative stress, such as measurement of lipid peroxidation and protein carbonyl compound as oxidative products from reactive oxygen species activity. Protein carbonyls believed chemically more stable than oxidative modification products from lipid. Another type of oxidative modification of protein is AOPPs. AOPPs are produced during oxidative stress as a result of myeloperoxidase activity in activated neutrophils acting on hypochloric acid and chloramines; these are a reliable marker to measure the oxidative modification of proteins [5]. Myeloperoxidase is an haeme-containing enzyme which secreted by the phagocytes after an activation from respiratory burst system. Myeloperoxidases are usually used as tissues neutrophil accumulation and neutrophil activity marker on plasma assays. Myeloperoxidase use hydrogen peroxides to oxidize amount of aromatic species ( $\mathrm{RH}$ ) by one electron mechanism to form aromatic radical $\left(\mathrm{R}^{\bullet}\right)$. This is typical. Therefore, they are ready to oxidize the strong non radical reactive oxygen species, the $\mathrm{HOCl}$ ions. $\mathrm{HOCl}$ is reactive oxygen species that produced by neutrophils and very bactericidals [3].

The oxidative modifications of proteins are more stable than lipids, making proteins good oxidative stress markers. Protein oxidation can result from the formation of protein carbonyls, formation of cross linked molecules by sulphydryl group oxidation, and formation of advanced oxidation protein products (AOPPs). AOPPs can be defined as dityrosine that includes cross linked proteins. This definition is important because it excludes protein aggregates that are formed as a result of disulphide bonding. Therefore, AOPPs may have a function as a marker for oxidative stress [6].

In sepsis, there are several potential sources of oxidative stress, including the mitochondrial respiratory electron transport chain, xanthine oxidase activation as a result of ischaemia and reperfusion, the respiratory burst associated with neutrophil activation, and arachidonic acid metabolism. Activated neutrophils produce superoxide as a cytotoxic agent as part of the respiratory burst via the action of membrane-bound NADPH oxidase on molecular oxygen.
Neutrophils also produce the free radical nitric oxide $\left(\mathrm{NO}^{\bullet}\right)$, which can reacts with superoxide to produce peroxynitrite, a powerful oxidant, which may decompose to form the hydroxyl radical. Under ischaemic conditions followed by subsequent reperfusion, the xanthine oxidase enzyme catalyses the formation of uric acid with the coproduction of superoxide [17], [18].

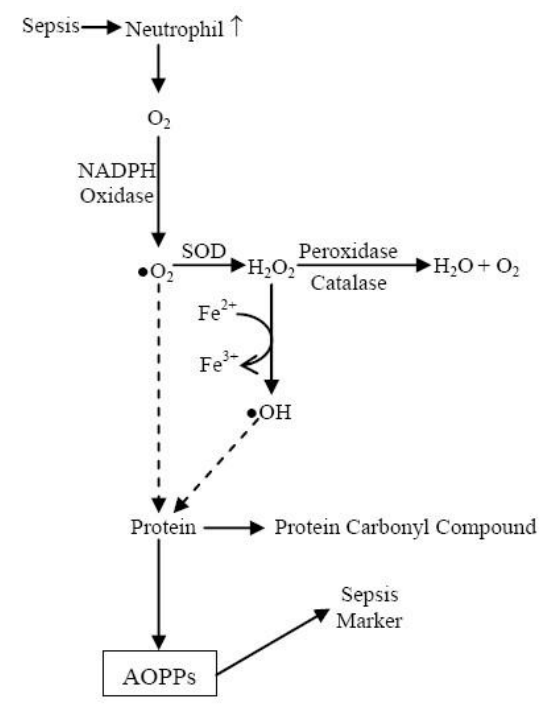

Fig. 2. AOPPs as novel neonatal sepsis marker.

This study suggests that there are some significant differences between AOPPs level, both from salivary and serum, on the case group (sepsis risked) and the control group (normal). It is similar with the protein carbonyl compounds level that shows its level higher in the case groups and it is significant while the production of hydrogen peroxides as the reactive oxygen species is also higher in the case group significantly. This study shows production of AOPPs and carbonyl compounds are significantly increase when there are any risk factor for neonatal sepsis. There is significant difference between salivary AOPPs level to the serum AOPPs level, likely the carbonyl compounds and the hydrogen peroxides. This study indicates, both AOPPs from saliva as well as from serum, significantly produced in neonatal sepsis and although amount of AOPPs that produce in saliva were different compare to serum AOPPs level. This suggested a marker role of AOPPs to detect oxidative stress on early-onset of neonatal sepsis which describe in Fig. 2.

AOPP has been used recently as oxidative stress marker for several disease. The involvement of AOPPs on oxidative stress has been used as marker for chronic renal failure, acute coronary syndrome, liver cirrhosis, and nasal polyposis [7], [8], [11], [17].

Several methods to diagnose early-onset neonatal sepsis have been reported, such as procalcitonin and c-reactive protein [9], [19], [20]. Based on the result of this study we proposed the use of AOPPs as the new marker for early-onset of neonatal sepsis. This study is similar with our previous study which uses salivary antioxidative index (SAOI) as a marker for early-onset of neonatal sepsis. Salivary antioxidative index is ratio of salivary enzymatic antioxidant activity to salivary hydrogen peroxide level, shows that any decrease of SAOI will contribute presence of sepsis about 3,7 fold. This study suggests a marker role of SAOI to detect oxidative stress on early-onset of neonatal sepsis [21]. 


\section{CONCLUSION}

As a conclusion, this study shows that there is significant difference of AOPPs level between the case group and the control group and also there is significant difference between salivary AOPPs level to serum AOPPs level of the newborn at risk of sepsis. This result suggests that this parameter may be used as another marker to detect early-onset neonatal sepsis.

\section{REFFERENCES}

[1] Z. Muhammad, A. Ahmed et al., "Neonatal sepsis: Causative bacateria and their resistance to antibiotics," JAMC, vol. 22, no. 4, pp. 33-36, 2010 .

[2] E. A. Marchant, G. K. Boyce, M. Sadarangani, and P. M. Lavole, "Neonatal sepsis due to coagulase-negative Staphylococci," CDI, vol. 2013, pp. 1-10, 2013.

[3] A. Yunanto, H. M. S. C. Kusuma et al., "Kuantitas, kualitas, dan daya fagositosis neutrofil pada saliva dan darah bayi baru lahir dengan faktor risiko sepsis," $J K B$, vol. 27, no. 2, Aug. 2012.

[4] A. Yunanto, P. Andayani et al., "Neutrophil phagocytosis activity compared to myeloperoxidase, hydrogen peroxidase and lactoferrin levels in saliva of newborn baby with sepsis risk factor to detect early-onset neonatal sepsis," IJPSI, vol. 2, pp. 18-22, Jan. 2013.

[5] R. Rossi, D. Giustarini et al., "Protein carbonyl groups as biomarkers of oxidative stress," Clinica Chimica Acta, vol. 329, pp. 23-38, 2003.

[6] B. Veyseller, F. Aksoy, B. Ertas, M. Keskin, O. Ozhuran, Y. S. Yilldirum, F. G. I. Bayraktar, and H. Ozturk, "A new oxidative stress marker in patients with nasal polyposis: advance oxidation protein products (AOPP)," B-ENT, vol. 6, pp. 105-109, 2010.

[7] M. Skvarilova, A. Bulava, D. Stejskal, S. Adamovska, and J. Bartek, "Increased level of advanced oxidation protein products (AOPP) as a marker of oxidative stress in patients with acute coronary syndrome,' Biomed. Papers, vol. 149, no. 1, pp. 83-87, June 2005.

[8] K. Simon, M. Warwas et al., "Advanced oxidation products and inflammatory markers in liver cirrhosis: A comparison between alcohol-related and HCV-related cirrhosis," Acta BP, vol. 58, no. 1, pp. 59-65, Mar. 2011.

[9] A. Aminullah, D. Gatot, M. S. Kosim, R. Rohsiswatmo, F. Indarso, R. Dharma et al., Penatalaksanaan Sepsis Neonatorum, Jakarta: Health Technology Assessment Indonesia \& Departemen Kesehatan Republik Indonesia, 2007, pp. 33-34.

[10] L. Selmeci, L. Seres, M. Antal, J. Lukács et al., "Advanced oxidation protein products (AOPP) for monitoring oxidative stress in critically ill patients: a simple, fast and inexpensive automated technique," Clin Chem Lab Med. vol. 43, no. 3, pp. 294-297, 2005.

[11] M. Friedlander, T. N. Khoa et al., "Advanced oxidation protein products as novel mediators on inflammation and monocyte activation in chronic renal failure," J Immunol, vol. 161, pp. 2524-2532, 1998.

[12] K. Uchida, M. Kanematsu, K. Sakai, T. Matsuda, N. Hattori, Y. Mizuno, D. Suzuki, T. Miyata, N. Noguchi, E. Niki, and T. Osawa, "Protein bound acrolein: Potential markers for oxidative stress," PNAS, vol. 95, pp. 4882-4887, April 1998.

[13] A. Castegna, J. Drake, C. Pocernich, and D. A. Butterfield, "Protein carbonyl levels-An assessment of protein oxidaation," in Methods in Pharmacology and Toxicology:Methods in Bioligical Oxidative Stress, K. Hensley and R. A. Floyd, Ed., Totowa, NJ: Humana Press, 2003, pp. 161-168

[14] E. Suhartono et al., "The role of cadmium in proteins glycation by glucose: Formation of methylglyoxal and hydrogen peroxide in vitro," JOMB, vol. 3, no. 1, March 2014
[15] D. Banerjee, P. A. Kumar, B. Kumar, U. K. Madhusoodanan, S. Nayak, and J. Jacob, "Determination of absolute hydrogen peroxide concentration by spectrophotometric method," Current Science, vol. 83 , no. 10 , Nov. 2002

[16] S. Cherian, S. Jameson, C. Rajarajeswari, V. Helena, L. L. A. Rekha, S. Raju, P. G. Kini, and A. Rao, "Oxidative stress in sepsis in children," IJMR, vol. 125, pp. 143-148, Feb. 2007.

[17] D. Viemann, G. Dubbel, S. Schleifenbaum, E, Harms, C. Sorg, and J. Roth, "Expression of Toll-Like Recxeptors in Neonatal Sepsis," Pediatr Res., vol. 58, no 4, pp 654-659, 2005.

[18] J. Macdonald, H. F. Galley, and N. R. Webster, "Oxidative stress and gene expression in sepsis," BJA, vol. 90, no. 2, pp. 21-32, 2003.

[19] U. K. Mishra, S. E. Jacobs, L. W. Doyle, and S. M. Garland, "Newer approaches to the diagnosis of early onset neonatal sepsis," ADCFN, vol. 91, pp. F208-F212, 2006

[20] S. K. Mondal, D. R. Nag, R. Bandyopadhyay, D. Chakraborthy, and S. K. Sinha, "Neonatal sepsis: Role of a battery of immunohematological tests in early diagnosis," IJABMR, vol. 2, pp. 43-47, Jan.-Jun. 2012

[21] A. Yunanto, R. T. Firdaus et al., "Salivary antioxidative index in newborns at risk of sepsis as novel parameter for early-onset neonatal sepsis," JOMB, vol. 3, no. 1, March 2014

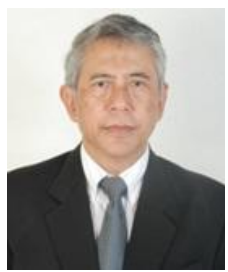

Ari Yunanto was born in Salatiga, Indonesia, November 1952. He is a physician since 1978 and pediatrician since 1989 from Diponegoro University, Semarang, Indonesia. He is neonatologist since 2005 , $\mathrm{PhD} 2012$ from Brawijaya University, Malang, Indonesia.

He currently work as neonatologist in Ulin General Hospital, Banjarmasin, Indonesia. His studies mainly focused in neonatal salivary and stress oxidative.

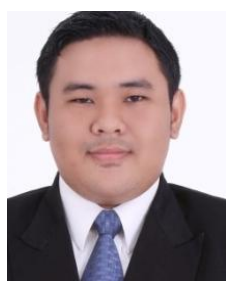

Rizky Taufan Firdaus was born in Balikpapan, Indonesia, in December 1983. He was graduated as physician from Lambung Mangkurat University, Banjarmasin, Indonesia in 2009.

$\mathrm{He}$ currently works as a general physician in Mutiara Bunda Mother and Child Hospital, Martapura, Indonesia. His studies mainly focused in oxidant and antioxidant on maternal, and perinatal medicine.

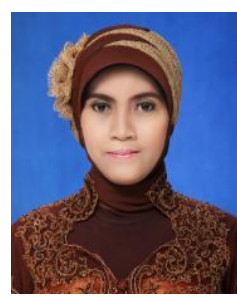

Triawanti was born in Surabaya, Indonesia, in September 1971. She was graduated as physician in 1998 from Lambung Mangkurat University, Banjarmasin, Indonesia. She was graduated master degree 2004 from Airlangga University, Surabaya, Indonesia, PhD 2012 from Brawijaya University, Malang, Indonesia.

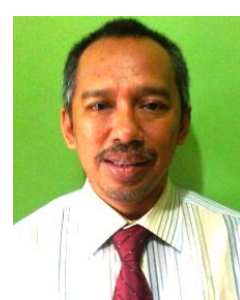

Eko Suhartono was born in Surabaya, Indonesia, in September 1968. He received his Bachelor degree from Sepuluh Nopember of Institute Technology in 1991 and M. Sc degree in 1998 from Gadjah Mada University, Yogyakarta, Indonesia.

He currently studies environmental science and technology graduate program in Brawijaya University, Malang, Indonesia. His research is mainly focused on free radical and natural product antioxidant,ecotoxicology. He has published more than 40 scientific journal or conference papers. 